\title{
Homovanillic Acid in the Cerebrospinal Fluid of Parkinsonian Patients
}

\author{
L. Cunha, A.F. Gonçalves, C. Oliveira, M. Dinis and R. Amaral
}

\begin{abstract}
SUMMARY: Determinations of CSF HVA before and after Probenecid administration were made in 41 patients with Parkinson's disease. The means of HVA concentration were lower than those of controls but no correlation with clinical data was found. A negative correlation was demonstrated between post-probenecid HVA levels and subsequent score improvement with L-DOPA at 3,6 and 12 months. Post-probenecid HVA levels suggest that there are distinct forms of parkinsonism and could predict the response to L-DOPA therapy.
\end{abstract}

RÉSUMÉ: Les concentrations de AHV dans le LCR avant et après Probenecid ont été mesurées chez 41 parkinsoniens. Les concentrations moyennes de AHV étaient au-dessous de celles des contrôles mais aucune corrélation avec les faits cliniques n'a pu être demontrée. On a trouvé une corrélation négative entre les niveaux de AHV post-probenecid et l'amélioration du "score" avec L-DOPA à 3,6 et 12 mois. Les niveaux de AHV post-probenecid, suggèrent des formes differentes de parkinsonisme et pourraient prédire la réponse au traitement par L-DOPA.

Can.J. Neurol. Sci. 1983; 10:43-46

Since the demonstration of a decrease in dopamine (DA) and homovanillic acid (HVA) in the striatum of patients with Parkinson's disease (Ehringer and Hornykiewicz, 1960; Bernheimer and Hornykiewicz, 1964, 1965) various approaches have been made to study DA metabolism through the concentration of its acid metabolites in cerebrospinal fluid (CSF). About one third of the HVA released in the striatum enters the CSF in the lateral ventricle intermittently (Sourkes, 1973; Wightman et al, 1978). Although the concentration of HVA in the ventricular CSF seems related to that in the striatum (Moir et al, 1970; Wightman et al, 1978) the initial "jet" of HVA diffuses in a circulating CSF and is partially cleared by an active transport mechanism (Ashcroft et al, 1968; Wolfson et al, 1978) so that the concentration in cisternal and lumbar CSF is lower and the correlation with striatal levels disappears (Roos, 1971; Sourkes, 1973; Garelis and Sourkes, 1973). This can be compensated for to some extent by the administration of probenecid which blocks the active transport mechanism, preventing the efflux of HVA from CSF (Guldeberg et al, 1966; Forn, 1972; Wolfson et al, 1978; Aizenstein and Korf, 1978).

Several papers have reported a decreased basal HVA at ventricular (Guldeberg et al, 1967; Papeschi et al, 1970) cisternal (Jéquier and Dufresne, 1972) and lumbar (Johansson and Roos, 1967; Godwin et al, 1971; Miachon et al, 1974; Davidson, 1977) levels in parkinsonian patients, as well as a decreased accumulation after probenecid administration (Olsson and Roos, 1968; Chase and Ng, 1971; Bowers and Van Woert, 1972; Rinne et al, 1973). Some discrepancies, possibly related to the methodology, were reported between the correlation of HVA concentrations and improvement scores after L-DOPA therapy. A negative correlation was found by some authors with basal (Jéquier and Dufresne, 1972; Gumpert et al, 1973; Miachon et al, 1974) as well as with post-probenecid levels (Lakke et al, 1971, 1973, 1974; Korf et al, 1974) but denied by others (Bowers and Van Woert, 1972; Chase and Ng, 1972; Rinne and Sonninen, 1972; Rinne et al, 1973; Weiner and Klawans, 1973).

To help clarify these problems, we studied 41 parkinsonian patients and determined CSF HVA before and after probenecid administration. The oral probenecid test as recommended by Chase and $\mathrm{Ng}$ (1972) was used, as the results are comparable to those obtained with intravenous infusion in spite of greater plasma and CSF probenecid concentrations and consequent gastrointestinal side effects (Kartzinel et al, 1976). Correlations with clinical data and with response to L-DOPA treatment at 3,6 and 12 months were attempted.

\section{MATERIAL AND METHODS}

Forty-one parkinsonian patients (28 males and 13 females, mean age $59.5 \pm 8.6$ ) were assessed with a rating scale for parkinsonian symptoms (Duvoisin, 1971) and were informed about the nature of the investigation. For three days before the lumbar puncture, the patients were kept on a diet that excluded all foods known to influence monoaminergic metabolism. None of them were taking any drug for at least three weeks before determination of CSF HVA.

From the Clinica Neurológica, Faculdade de Medicina da Universidade de Coimbra, Coimbra, Portugal.

Received July 30, 1982. Accepted for publication November 30, 1982.

Address reprint requests to Prof. L. Cunha, Clínica Neurológica, Hospitais da Universidade de Coimbra, 3000 - Coimbra, Portugal. 
In 33 patients a lumbar puncture was done to determine basal HVA values. In 36 patients the post-probenecid HVA value was determined after 6 grams of oral probenecid given in divided doses over three hours. The lumbar puncture was done three hours after the last dose.

Patients remained recumbent in bed throughout the study as well as during the preceding 12 hours. The samples of CSF were stored at $-20^{\circ} \mathrm{C}$ until the HVA determination was carried out using the method of Gerbod and Bowers (1968). Sixteen patients without known disturbance of monoaminergic metabolism or CSF dynamics were used as controls.

L-DOPA in combination with a decarboxylase inhibitor was started after the test and improvement scores were calculated from the difference between the initial score and the results after 3,6 and 12 months of therapy. The $t$ test for independent samples was used for statistical comparison of the means.

\section{RESULTS}

The data concerning HVA concentrations are summarized in table 1 . Basal $(40.5 \pm 20.9 \mathrm{ng} / \mathrm{ml})$ and post- probenecid $(69.7 \pm 39.4 \mathrm{ng} / \mathrm{ml})$ values are lower than those of controls $(53.6 \pm 38.9 \mathrm{ng} / \mathrm{ml}$ and $136.2 \pm 35.0 \mathrm{ng} / \mathrm{ml}$ respectively) but only the last value attains statistical significance $(p<0.001)$. There was no consistent correlation between HVA levels and age of patients, severity of illness or individual symptoms such as rigidity, tremor, bradykinesia and impairment of postural reflexes (table 2). The duration of illness was difficult to access in the majority of patients and its correlation with HVA was variable.

Fig. 1 shows the relationship between CSF postprobenecid HVA levels and the improvement scores after 3 months of L-DOPA therapy in 32 patients. A negative correlation between these values, reaches a high statistical significance $(r=-0.57 ; p<0.001)$. This correlation persists after 6 and 12 months of L-DOPA therapy, but the level of significance is lower because of the smaller number of patients studied ( 27 and 20 respectively). In general, the patients who improved with L-DOPA therapy were slightly younger and had a significantly lower post-probenecid HVA. No other significant differences could be found in the total or partial disability scores (table 2 ).

TABLE 1

Concentration of $H V A$ in Lumbar $C S F$

\begin{tabular}{|c|cc|cc|}
\hline \multirow{2}{*}{} & \multicolumn{2}{|c|}{ BASAL/H V A } & \multicolumn{2}{c|}{ POST-PROBENECID/H V A } \\
\cline { 2 - 6 } & Controls & Parkinson's Disease & Controls & Parkinson's Disease \\
\hline NUMBER & 16 & 33 & 16 & 36 \\
\hline $\begin{array}{c}\text { MEAN VALUE } \\
(\mathrm{ng} / \mathrm{ml})\end{array}$ & $53.6 \pm 38.9$ & $40.5 \pm 20.9$ & $136.2 \pm 35.0$ & $69.7 \pm 39.4$ \\
\hline $\mathrm{p}$ & \multicolumn{2}{|c|}{ n.s. } & \multicolumn{2}{c|}{$<0.001$} \\
\hline
\end{tabular}

TABLE 2

Correlation of Improvement Scores with Clinical Data and Post-Probenecid H VA

Improvement Improvement Total Scores $>\mathbf{2 0 \%}$ Scores $<20 \%$

\begin{tabular}{lrrr} 
Number of Patients & 22 & 10 & 32 \\
Age & 57.8 & 61.8 & 59.0 \\
& \pm 8.5 & \pm 7.3 & \pm 8.1 \\
Rigidity Score & 11.9 & 10.2 & 11.4 \\
& \pm 3.8 & \pm 3.6 & \pm 3.8 \\
Tremor Score & 6.7 & 5.9 & 6.4 \\
& \pm 4.9 & \pm 4.1 & \pm 4.7 \\
Bradykinesia Score & 25.0 & 18.7 & 23.0 \\
& \pm 9.3 & \pm 6.1 & \pm 8.9 \\
Total Initial Score & 49.9 & 44.7 & 48.3 \\
& \pm 15.5 & \pm 12.0 & \pm 14.7 \\
Total Score at & 29.5 & 45.2 & 34.4 \\
3 Months Therapy & \pm 10.7 & \pm 11.6 & \pm 13.0 \\
H V A Post-Probenecid & 53.3 & 113.8 & 72.2 \\
& \pm 29.0 & \pm 31.8 & \pm 40.3 \\
& & $\mathrm{p}<0.001$ & \\
\hline
\end{tabular}

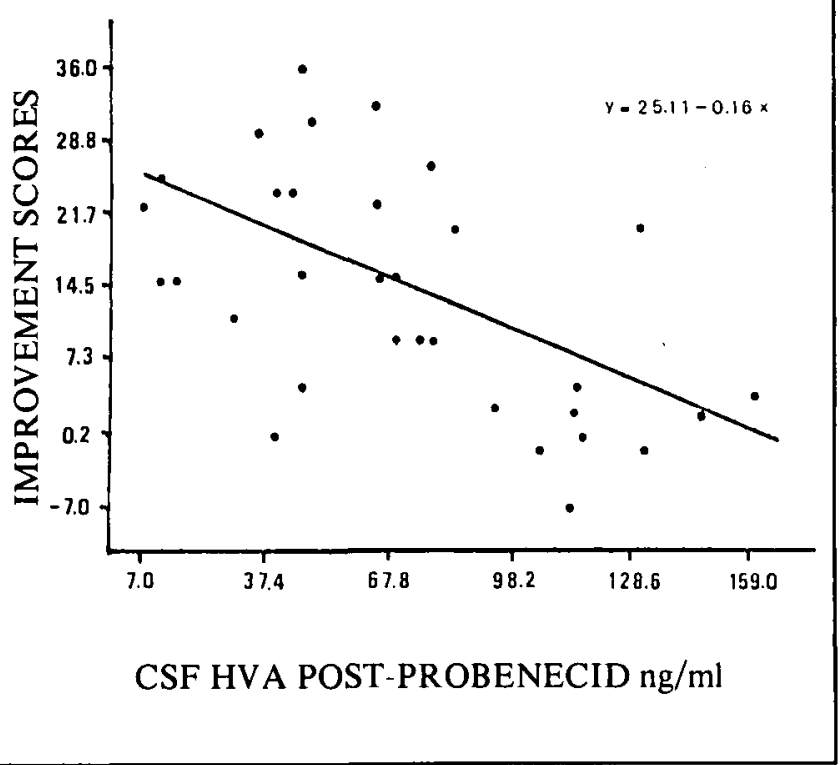

Figure 1 - Relationship between CSF post-probenecid HVA levels and improvement scores with L-DOPA. 


\section{DISCUSSION}

We have previously identified two groups of parkinsonian patients based on a retrospective analysis of rate of deterioration and response to L-DOPA therapy (Gonçalves et al, 1981; Cunha et al, 1982). The first group showed rapid deterioration after a beneficial response to L-DOPA and frequent "on-off" phenomena. The second group with higher mean age, responded less well to L-DOPA and presented only occasional "on-off" phenomena. In the present study we attempted to trace biochemical differences between these groups, but failed to find any correlation between CSF HVA levels and duration, severity or clinical manifestations of disease.

However, a negative correlation was demonstrated between post-probenecid CSF HVA levels and response to L-DOPA therapy, confirming the report of Lakke et al (1971). Post-probenecid HVA levels could have predictive value in the assessment of responsiveness to L-DOPA. Higher values would predict a poor response to L-DOPA and would probably imply damage to nondopaminergic neurons (Lakke, 1974) or a more diffuse disease. In favour of this hypothesis, post-mortem studies of the brain of some parkinsonian patients do not reveal significant cell loss in the nigrostriatal system (Forno and Alvord, 1971; Bøettcher, 1975). A "multineuronal type" of parkinsonism with involvement of NA, DA, and serotoninergic neurons has been suggested (Barbeau, 1976; Granerus et al, 1979).

On the other hand, lower levels of HVA reflecting a real striatal DA deficiency, could predict a good response to LDOPA. This would imply that the DA synthesizing enzyme DOPA decarboxylase (mainly produced by DA cells) is present and that DA receptors are intact. This is not the case in more advanced forms of the disease where the enzyme deficiency and the receptor degradation could be factors which limit the response to L-DOPA.

We would like to stress the importance of standardizing the methods for determining HVA concentrations if CSF HVA levels are to be used to predict the response to $\mathrm{L}$ DOPA. We recommend the probenecid method used in this paper. Even with this approach there are some uncertainties, but our results provide further evidence to support the hypothesis that there are two clinical and possibly etiological distinct sub-groups of parkinsonian patients.

\section{ACKNOWLEDGEMENT}

We wish to thank Dr. E. Ponciano for statistical assistance.

\section{REFERENCES}

Aizenstein, M.L., and Korf, J. (1978). Aspects of influx and efflux of HVA of rat CSF. Brain Res., 149:129-140.

Ashcroft, G.K., Dow, R.C., Moir, A.T.B. (1968). The active transport of 5-hydroxyindol-3-ylacetic acid and 3methoxy-4-hydroxyphenylacetic acid from a recirculatory perfusion system of the cerebral ventricles of the unanaesthetized dog. J. Physiol. (Lond), 199:397-425.

Barbeau, A. (1976). The nonsurgical treatment of "Parkinson's disease": a personal view. Current controversies in Neurosurgery (ed. by T.P. Morley) W.B. Saunders Company, pp. 419-434.
Bernheimer, H., and Hornykiewicz, O. (1964). Das verhalten des Dopamin-metaboliten Homovanillinsaure im gehirn von normalen und Parkinson-kranken Menschen. Naunyn-Schmiedeberg's Arch. exp. Path. Pharmak., 247:305.

Bernheimer, H., and Hornykiewicz, O. (1965). Herabgesetzte konzentration der homovanillinsaure im gehirn von parkinsonkraken menschen als ausdruck der storung des zentralen dopaminstoffwechsels. Klin. Wschr, 43:711-715.

Bøettcher, J. (1975). Morphology of the basal ganglia in Parkinson's disease. Acta Neurol. Scand., Suppl. 62,52.

Bowers, M.B. Jr., and Van Woert, M.H. (1972). The probenecid test in Parkinson's disease. Lancet, 2:926927.

Chase, T.N., and Ng, L.K.Y. (1971). Probenecid test in Parkinson's disease. Lancet, 2:1265-1266.

Chase, T.N., and Ng, L.K.Y. (1972). Central monoamine metabolism in Parkinson's disease. Arch. Neurol. Chicago, 27:486-491.

Cunha, L., Gonçalves, A.F., Diniz, M., Amaral, R., Ferro, M.A. (1982). Problemas na terapêutica do parkinsonismo pela L-DOPA. Psiquiatria Clínica. In Press.

Davidson, D.L.W., Yates, C.M., Mawdsley, C., Pullar, I.A., Wilson, H. (1977). CSF studies on the relationship between Dopamine and 5-Hydroxytryptamine in parkinsonism and other movement disorders. J. Neurol. Neurosurg. Psychiatry, 40:1136-1141.

Duvoisin, R.C. (1971). The evaluation of extrapiramidal disease. Monoamines noyaux gris centraux et syndrome de Parkinson. J. de Ajuriaguerra. Ed. Paris: Masson et Cie, 313-326.

Ehringer, H., Hornykiewicz, O. (1960). Verteilung von Noradrenalin und Dopamine (3-Hydroxytryramine) im Gehirn des Menschen und ihr Verhalfen bei Erkrankungen des extrapyramidalen system. Klin. Wschr.; 38:1236.

Forn, J. (1972). Active transport of 5-Hydroxindoleacetic acid by the rabbit choroid plexus in vitro. Blockade by Probenecid and metabolic inhibitors. Biochem. Pharmac. 21:619-624.

Forno, L.S., and Alvord, E.C. (1971). The pathology of Parkinsonism. Recent advances in Parkinson's disease. Edit. by F.H. McDowel and C.H. Markham, Blackwell Scientific Publications, Oxford, pp. 131-161.

Garelis, E., Sourkes, T.L. (1973). Sites of origin in central nervous system of monoamine metabolites measured in cerebrospinal fluid. J. Neurol. Neurosurg. Psychiatry. 36:625-629.

Gerbod, F.A., Bowers, M.D. (1968). Measurement of acid monoamine metabolites in human and animal cerebrospinal fluid. J. Neurochemistry, 15:1053-1055.

Godwin-Austen, R.B., Kantamaneni, B.D., Curzon, G. (1971). Comparison of benefit from L-DOPA in Parkinsonism with increase of amine metabolites in the CSF. J. Neurol. Neurosurg. Psychiat., 34:219-223.

Gonçalves, A.F., Cunha, L., Diniz, M., Amaral, R., Ferro, M.A. (1981). Alguns aspectos do tratamento do parkin- 
sonismo. Reunião Sociedade Portuguesa Neurologia e Psiquiatria. Coimbra, 1981.

Granerus, A.K., Carlsson, A., Svanborg, A. (1979). The aging neuron. Influence on symptomatology and therapeutic response in Parkinson's symptoms. Advances in Neurobiology (Eds. Poirier, L.J., Sourkes, T.L., Bédard, P.J.), Vol. 24, pp. 327-334.

Guldberg, H.C., Ashcroft, G.W., Crawford, T.B.B. (1966). Concentrations of 5-Hydroxyindoleacetic acid and homovanillic acid in the cerebrospinal fluid of the dog before and during treatment with probenecid. Life Sciences, 5:1570-1575.

Guldberg, H.C., Turner, J., Hanieh, A., Ashcroft, G.W., Crawford, T.C., Perry, W., and Gillinghan, F.J., (1967). On the occurrence of HVA and 5-HIAA in the ventricular CSF of patients suffering from Parkinsonism. Confin. Neurol. (Basel) 29:73.

Gumpert, E.J.N., Sharp, D.M. and Curzon, G. (1973). Amine metabolites in the cerebrospinal fluid in Parkinson's disease and the response to L-DOPA. J. Neurol. Sci. 19:1-12.

Jéquier, E., and Dufresne, J.J. (1972). Biochemical investigations in patients with Parkinson's disease treated with L-DOPA. Neurology 22:15-21.

Johansson, B., and Roos, B.E. (1967). 5-Hydroxyindoleacetic acid and homovanillic acid levels in the cerebrospinal fluid of healthy volunteers and patients with Parkinson's Syndrome. Life Sci. 6:1449-1454.

Kartzinel, R., Ebert, M., Chase, T. (1976). Intravenous probenecid loading. Effects on plasma and CSF probenecid levels and on monoamine metabolites in CSF Neurology, 26:992-996.

Korf, J., Van Praag, H.M., Schut, D., Nienhuis, R.J., Lakke, J.P.W.F. (1974). Parkinson's disease and amine metabolites in cerebrospinal fluid: implications for LDOPA therapy. Europ. Neurol., 12:340-350.

Lakke, J.P., Korf, J. and Van Praag, H.M. (1971). Predicting response to levodopa. Lancet, 2:164-165.

Lakke, J.P., Korf, J., Van Praag, H.M., Minderhoud, J., Schut, T. (1973). Clinical significance of Probenecid test. Lancet, 614-615.

Lakke, J.P., Nienhuis, R.J., Schut, T. and Korf, J. (1974). The probenecid test and the effect of L-DOPA treatment: clinical application of the probenecid test and its limitations in disorders of the Basal Ganglia. Current Concepts in the Treatment of Parkinsonism, MD Yahr. New York: Raven Press, 37-60.

Miachon, S., Dalmaz, Y., Cottet-Emard, J.M., Peyrin, L. (1974). Cerebrospinal homovanillic acid and Parkinsonism. Biomedicine, 20:303-308.

Moir, A.T.B., Ashcroft, G.M., Crawford, T.B.B., Eclieston, D., Guldberg, H.C. (1970). Cerebral metabolites in cerebrospinal fluid as a biochemical approach to the brain. Brain, 93:357-368.

Olsson, R., and Roos, B.E. (1968). Concentrations of 5hydroxyindoleacetic acid and homovanillic acid in cerebrospinal fluid after treatment with probenecid in patients with Parkinson's disease. Nature, 219:502-503.

Papeschi, R., Molina-Negro, D., Sourkes, T.L., Hardy, J., and Bertrand, C. (1970). Concentrations of homovanillic acid in the ventricular fluid of patients with Parkinson's disease and other dyskinesias. Neurology, 20:991-995.

Rinne, U.K., and Sonninen, V. (1972). Acid monoamine metabolites in the cerebrospinal fluid of patients with Parkinson's disease. Neurology, 22:62-67.

Rinne, U.K., Sonninen, V. and Siirtola, T. (1973). Acid monoamine metabolites in the CSF of Parkinsonian patients treated with Levodopa alone or combined with a decarboxylase inhibitor. Europ. Neurol. 9:349-362.

Roos, B.E. (1971). Metabolites of monoamines in the cerebrospinal fluid (CSF). Monoamines, Noyaux Gris Centraux et Syndrome de Parkinson. Ed. J. de A juriaguerra, Paris: Masson et Cie, 119-128.

Sourkes, T.L. (1973). Enzymology and sites of action of monoamines in the central nervous system. Advances in Neurology, 2:13-36. New York: Raven Press.

Weiner, W.I. and Klawans, H.L. (1973). Failure of cerebrospinal fluid homovanillic acid to predict levodopa response in Parkinson's disease. J. Neurol. Neurosurg. Psychiatry, 36:747-752.

Wightman, R.M., Strope, E., Plotsky, P., Adams, R.N. (1978). In vivo voltammetry: monitoring of Dopamine metabolites in CSF following release by electrical stimulation. Brain Res., 159:55-68.

Wolfson, L.I., Katzman, R., Escriva, A. (1978). Clearance of amine metabolites from the cerebrospinal fluid: The brain as a "sink". Neurology, 24:772-779. 